\title{
Expression of ESR1 and ESR2 oestrogen receptor encoding gene and personality traits - preliminary study
}

\author{
Monika E. Talarowska', Janusz Szemraj², Su Kuan-Pin ${ }^{3}$ \\ ${ }^{1}$ Department of Personality and Individual Differences, Institute of Psychology, University of Lodz, Poland \\ ${ }^{2}$ Department of Medical Biochemistry, Medical University of Lodz, Poland \\ ${ }^{3}$ Department of General Psychiatry, China Medical University Hospital, Taichung City, Taiwan
}

\begin{abstract}
Introduction: The main objective of the study is to examine the hypothesis claiming a correlation between personality traits measured with the use of the Minnesota Multiphasic Personality Inventory (MMPI-2) personality questionnaire and the expression of the ER $\alpha(E S R 1)$ and ER $\beta$ (ESR2) encoding gene in patients suffering from depression.

Material and methods: The experiment was carried out on a group of 44 individuals with depression. The Polish variant of the MMPI-2 was applied with the aim of assessing personality traits. Furthermore, the authors evaluated the expression of the genes encoding the oestrogen receptors (ER $\alpha$ and ER $\beta$ ) at the mRNA level and protein level in the studied population.

Results: No significant differences in the expression of ER $\alpha$ and ER $\beta$ encoding genes were found and confirmed in the patients with the first episode of depression and those suffering from subsequent episodes of the disease. No differences were found between women and men, either. In women a positive relationship was found between the scale of psychopathy $(p=0.04)$, paranoia $(p=0.01)$, and mania $(p=0.03)$ and expression for the ER $\alpha$ encoding gene at the mRNA level. A negative relationship was found between the mania scale and ER $\beta$ encoding gene expression at mRNA $(p=0.03)$ and protein $(p=0.04)$ levels. In males a positive relationship between anxiety as a personality trait and expression of the ER $\beta$ receptor encoding gene at mRNA level $(p=0.03)$ and protein level $(p=0.03)$ was found.

Conclusions: Personality traits may be linked with the expression of genes encoding oestrogen receptors (ER $\alpha$ and ERB) among patients with depressive disorders.
\end{abstract}

Key words: oestradiol, ERs, depression, personality traits.

\section{Introduction}

Oestrogens are steroids responsible for the correct development and maintenance of homeostasis [1]. They are formed from cholesterol as a result of aromatisation of androgens under the influence of enzymes from the P450 cytochrome group located in the internal mitochondrial membrane [2, 3]. Oestrogens produced in the human body include estrone, $17 \beta$-oestradiol (E2) and oestriol $[4,5]$.

Oestrogens perform important biological functions in many human body systems, and thus disorders of signalling pathways in the oestrogenic response become the source of numerous diseases (e.g. cancer, cardiovascular diseases or neurodegenerative, metabolic, and immune diseases) $[6,7]$. They also play a significant role in the aetiology of various mental disorders, mood disorders in particular $[8,9]$.
Oestrogens in the central nervous system (CNS) are involved in neuroprotective activity and neuronal activity regulation $[10,11]$. They take part in the process of differentiating between the parts of the brain responsible for social and sexual behaviour [12, 13] (in the study by Mogi et al. [13], expression of oestrogen receptor $\alpha[E R \alpha]$ at mRNA levels in the hypothalamus and hippocampus was higher in male mice than in female mice before birth, while mRNA expression of oestrogen receptor $\beta[E R \beta]$ in the prefrontal cortex was higher in female mice immediately after birth). Oestrogens are also attributed a significant share in the regulation of motivational processes (including reproductive behaviour), social behaviour, and aggression [14], as well as memory processes and attention [15-17].

The regulation of congenital and acquired immunity is affected by oestrogens, particularly oestradiol [18]. 
The direction of action of oestrogens is largely dependent on their concentration. In low oestrogen concentrations (e.g. in men or in women during menstruation or menopause), proinflammatory cytokines are stimulated and produced, leading to an enhanced cellular response. In women the number of Th2 and B lymphocytes decreases significantly during menopause, while the number of Tc lymphocytes increases, and the application of hormone replacement therapy reverses this phenomenon. In turn, high oestrogen levels, such as those observed in women during ovulation and pregnancy, result in increased antibody production as well as enhancement - depending on Th2 lymphocytes - of the humoral immune response and increased release of Treg lymphocytes. Oestrogens also inhibit NK cells and reduce the inflow of neutrophils and monocytes, hindering their chemotaxis and migration to the inflammatory focus, hence protecting the body against long-term inflammation [19-21].

Oestrogen receptors $\alpha$ (ER $\alpha, N R 3 A 1$ - nuclear receptor subfamily 3 , group $A$, member 1$)$ and $\beta$ (ER $\beta$, NR3A2 - nuclear receptor subfamily 3 , group $A$, member 2 ) are steroid hormone receptors found in the nuclear receptor subfamily NR3 $[22,23]$. They are encoded by separate genes, and expression of both these receptors occurs in cells of multiple tissues; however, ER $\alpha$ predominance is found in the cells of the mucous membrane of the uterus, ovary, hypothalamus, and ducts of testes, while ER $\beta$ predominates in the cells of kidney, brain, heart, bone, lung, intestinal mucosa, prostate gland, and vascular endothelium [24]. ER receptors are located in cells in both cytoplasm and nucleus. Their location is not permanent, but the process is rather dynamic a result of translocation from and to the cell nucleus $[25,26]$. Both $E R \alpha$ and $E R \beta$ regulate the synthesis and metabolism of many neurotransmitters and neuropeptides, their receptors, and transporters, and also play a role in non-genomic cell signalling (the so-called rapid mechanism of action) [3, 27]. This makes ER essential for CNS development by regulating neuronal and glial proliferation, migration, differentiation, activation, and apoptosis of neurons [28, 29]. Oestrogen receptors can also be found in the immune system cells, e.g. in/on B lymphocytes, Th and Tc lymphocytes, NK, monocytes, macrophages, and dendritic cells [30].

With the neurodevelopmental theory of depression [31] (which underlines the importance and impact of earlier stages of human life, including the prenatal period, on the occurrence of depressive disorders) being the starting point for our considerations, and referring to the results of our earlier studies, in which we showed a correlation between personality traits and active inflammatory process indicators in depressed patients $[32,33]$, we adopted - as the aim of the presented paper - the hypothesis that personality traits measured by the Minnesota Multiphasic Personality Inventory (MMPI-2) personality questionnaire and the expression of the gene encoding ER $\alpha$ (ESR1) and ER $\beta$ (ESR2) in patients treated due to a depression episode are related.

\section{Material and methods}

\section{Potients}

Forty-four individuals diagnosed with depression took part in the experiment. Qualification to participate in the study was based on random selection principles. All the qualified subjects were native Poles, inhabitants of central Poland, aged 20-60 years. They were not related to one another. The inclusion clinical criteria in the research study were in accordance with the ICD-10 guidelines (F32.0-7.32.2, F33.0-F33.8) and based on the diagnostic criteria determining a depressive episode as well as recurrent depressive disorders [34]. The process of qualifying subjects for the experiment was performed by a psychiatrist.

The exclusion criteria in the research study were as follows: history of psychiatric disorders other than depression; somatic diseases that may affect depression; central nervous system trauma; history of autoimmune and inflammatory diseases and cancer; excessive use of, or addiction to, psychoactive substances; and lack of consent to participate in the experiment.

The study was carried out while the patients were hospitalised. The fact that the experiment was conducted had no impact on the treatment modalities applied by the specialists during the patients' hospital stay (pharmacotherapy, psychotherapy).

All patients were asked to give written consent for participation in the study, in compliance with the report approved by the Bioethics Committee of the Medical University of Lodz (approval no. RNN/534/10/KB of 07/09/2010).

\section{Methods}

The Hamilton Depression Rating Scale (HDRS, HAM-D), developed and introduced by Hamilton in 1960 , served as a tool for the evaluation of the dynamics of intensity of recurrent depressive disorder symptoms. Cronbach's $\alpha$ ( $\tau$-equivalent reliability) calculated for this scale totalled on average 0.70; the sensitivity coefficient was 0.78 , and test relevance coefficient was 0.75 [35]. When analysing the severity of depressive episode symptoms, a special scoring system worked out by Demyttenaere and De Fruyt was used [36].

Furthermore, the Composite International Diagnostic Interview (CIDI) questionnaire (version 3.0) was used in the experiment. This tool is based on the diagnostic criteria of the ICD-10 and DSM-IV classifications and is recommended by the $\mathrm{WHO}$ and $\mathrm{WMH}$ for epidemiological studies in psychiatry. It enables the estimation of dissem- 
ination of mental disorders and the evaluation of their advancement and subjective burden of the disease [37].

The MMPI-2 by Hathaway and McKinley, the Polish version of which was adapted by Kucharski [38], was used to assess personality traits. The result of the standard examination procedure is a profile consisting of four indicators of its accuracy and results of 10 clinical scales: hypochondria $(\mathrm{Hs})$, depression (D), hysteria (Hy), psychopathic disorders (Pd), masculinity - femininity (Mf), paranoia $(\mathrm{Pa})$, psychasthenia $(\mathrm{Pt})$, schizophrenia $(\mathrm{Sc})$, mania (Ma), and social introversion (Si) [39].

The severity of depressive disorders as well as results of psychological tests were in each case assessed and evaluated by the same clinical psychologist. Patient qualification to participate in the study was performed by the same psychiatrist.

The CIDI questionnaire was applied to the process of qualifying patients for participation in the experiment. The MMPI-2 and the HDRS test were used once the patients were qualified and approved to take part in the examination.

\section{Statistical analysis}

When analysing the collected materials, specific methods of descriptive statistics and statistical reasoning were applied. A two-tailed critical area was assumed for the statistical verification of the hypotheses stated in the introduction.

Appropriate structure indicators, for example the existence of a specific trait expressed in percentage terms, were used to describe qualitative features in both the affected patients and the control subjects. The arithmetic mean (M) was calculated with the intention to describe average quantitative features. The range of values (minimum and maximum values) as well as standard deviation (SD) were adopted as measures of dispersion.

The Shapiro-Wilk test served as a tool for the examination of the nature of the distribution of all the variables. The hypothesis on the normality of distribution was rejected. Non-parametric variables were examined using the Mann-Whitney $U$ test in order to make statistical comparisons between the examined groups. The authors used Spearman's rank correlation coefficient to examine the relationships between the analysed variables. The materiality level with regard to all the statistical methods applied totalled $p<0.05$ [40]. All statistical calculations were performed in STATISTICA PL (version 12).

\section{Assessment of ER $\alpha$ and $E R \beta$ encoding gene expression of the level of $\mathrm{mRNA}$ and protein level \\ Isolation of mRNA from total RNA}

The blood collected from the participants using EDTA as an anticoagulant was used to perform all the antici- pated analyses. The blood was collected during the hour after overnight fasting, i.e. between 7 a.m. and 8 a.m. Two samples of the blood were taken in each case, i.e. whole blood for gene expression and the second with plasma intended for protein level measurement.

RNA was isolated from the whole blood following the manufacturer's instructions. The RNA concentration was assessed using spectrophotometry by measuring absorbance at 260 and $280 \mathrm{~nm}$ (NanoDrop ND-1000 Spectrophotometer, Thermo Fisher Scientific, USA). cDNA synthesis was performed using a High Capacity RNA to cDNA kit (Applied Biosystem). Samples qualified for the next biological protocols had a final concentration of $200 \mathrm{ng} / \mathrm{\mu l}$ and an $\mathrm{A}_{260 / 280}$ ratio of 1.6-2.0.

Quantitative PCR in real time was carried out using SYBR Green Master Mix in 7500 Real-Time PCR (Applied Biosystems, Foster City, CA, USA). Experiments were performed in duplicate for each data point and the abundance of human ribosomal protein S26 mRNA was determined as a reference gene.

\section{Profein expression}

Protein level was tested in plasma by ELISA Kit (EIAabTM Germany) according to the manufacturer's instructions with the use of the quantitative sandwich enzyme immunoassay technique and a monoclonal antibody specific for oestrogen receptor. Plasma was collected using EDTA as an anticoagulant. The samples were centrifuged for 15 minutes at $1000 \times \mathrm{g}$ at $2-8^{\circ} \mathrm{C}$ within 30 minutes of collection and then stored at $\leq-20^{\circ} \mathrm{C}$.

All the results were interpreted by two researchers within a blinded experiment.

\section{Results}

Table 1 includes all the social and demographic characteristics of the experiment group. It also contains relevant data on the course of the disease. The subjects were divided into patients diagnosed with the first episode of depression (ED-I) and those with recurrent depressive disorders (rDE). No statistically significant differences in the age of the subjects in both groups were found and confirmed.

\section{Descriptive statistics of the variables}

Tables 2 and 3 include descriptive statistics of the variables analysed by the authors: scales of the MMPI-2 questionnaire and expression for the gene encoding ER $\alpha$ and ER $\beta$ receptors at the level of MRNA and protein level. We also compared the variables analysed between patients with the first and subsequent episodes of depression (Table 2) and between women and men (Table 3). 
In the first case, differences of statistical significance were found and confirmed in only two scales of the MMPI-2 test, i.e. the scale of schizophrenia and the scale of anxiety (Table 2). These results, significantly higher in the patients with subsequent episodes of depression, indicate the intensification of symptoms related to the sense of social and emotional alienation, lack of ego control in the cognitive and volitional spheres (these features are measured by the scale of schizophrenia), as

Table 1. Demographic features and the course of the disease in the studied group $(n=44)$

\begin{tabular}{|c|c|c|c|}
\hline Feature & $\begin{array}{c}\text { All subjects } \\
n=44\end{array}$ & $\begin{array}{c}\text { ED-I } \\
n=17\end{array}$ & $\begin{array}{c}\text { rDE } \\
n=27\end{array}$ \\
\hline $\begin{array}{l}\text { Age (years) } \\
M(S D)\end{array}$ & $45.54(10.74)$ & $44.37(12.52)$ & 46.15 (9.94) \\
\hline $\begin{array}{l}\text { Women/men } \\
n(\%)\end{array}$ & $\begin{array}{c}31 / 13 \\
(70.45 / 29.54)\end{array}$ & $\begin{array}{c}13 / 4 \\
(81.25 / 18.75)\end{array}$ & $\begin{array}{c}18 / 9 \\
(66.67 / 33.33)\end{array}$ \\
\hline $\begin{array}{l}\text { HDRS-I } \\
M(S D)\end{array}$ & $22.41(6.88)$ & $21.37(8.02)$ & 22.48 (5.69) \\
\hline $\begin{array}{l}\text { HDRS-II } \\
M(S D)\end{array}$ & 7.03 (4.59) & $6.67(4.72)$ & $7.25(4.61)$ \\
\hline $\begin{array}{l}\text { Number of } \\
\text { depressive } \\
\text { episodes } \\
M(S D)\end{array}$ & $3.38(4.11)$ & - & $5.13(4.91)$ \\
\hline $\begin{array}{l}\text { Duration of } \\
\text { disease (years) } \\
\text { M (SD) }\end{array}$ & $5.07(4.67)$ & $1.71(1.21)$ & $7.51(4.02)$ \\
\hline
\end{tabular}

HDRS I - Hamilton Depression Rating Scale on the day of qualification for the study, HDRS II - Hamilton Depression Rating Scale after response to pharmacotherapy, ED-I - patients with the first episode of depression, $\mathrm{rDE}$ - patients with recurrent depressive disorders well as an increased level of anxiety as a constant personality trait, which in turn translates into anxiety sensitivity and consequently leads to subsequent episodes of the disease. In the second case of sex-differentiated comparisons (Table 3), statistically significant differences concern only the scale of masculinity-femininity, which assesses the intensity of personality traits consistent with female and male social roles. Nevertheless, no significant differences were observed or found in the expression of the genes encoding ER $\alpha$ and ER $\beta$ receptors in the subjects with the first episode of depression and with subsequent episodes (Table 2). The differences between men and women were not confirmed (Table 3).

\section{Analysis of correlations}

The results of the correlation analysis carried out separately for the examined women and men revealed the following relationships:

- Women - positive relationship between the scale of psychopathy $(R=0.36, p=0.04)$, paranoia $(R=0.43$, $p=0.01)$, and mania $(R=0.38, p=0.03)$ and expression at the mRNA level for the gene encoding the ER $\alpha$ receptor. Negative relationship between the mania scale and $E R \beta$ receptor encoding gene expression at $\mathrm{mRNA}$ $(R=-0.39, p=0.03)$ and protein $(R=-0.36, p=0.04)$ levels.

- Men - positive relationship between anxiety as a personality trait and expression of the ER $\beta$ receptor encoding gene at mRNA level $(R=0.69, p=0.03)$ and protein level $(R=0.72, p=0.03)$.

Table 2. Descriptive statistics of the analysed variables - number of episodes of the disease

\begin{tabular}{|c|c|c|c|c|}
\hline $\begin{array}{l}\text { Variable } \\
\text { Me (SD) }\end{array}$ & $\begin{array}{c}\text { All subjects } \\
n=44\end{array}$ & $\begin{array}{c}\text { ED-I } \\
n=17\end{array}$ & $\begin{array}{c}\text { rDE } \\
n=27\end{array}$ & $\begin{array}{c}\text { ED-I vs. rDE } \\
\text { Mann-Whitney } \\
U \text { test }\end{array}$ \\
\hline Hypochondria scale $(\mathrm{Hd})$ & $73.682(15.08)$ & $71.125(14.77)$ & $74.667(15.41)$ & 0.889 \\
\hline Depression scale (D) & $78.068(14.21)$ & $75.125(13.74)$ & $80.185(14.52)$ & 0.842 \\
\hline Hysteria scale (Hy) & $72.773(15.97)$ & $69.813(16.91)$ & $73.519(14.91)$ & 0.556 \\
\hline Psychopathic deviate scale $(\mathrm{Pd})$ & $67.318(13.54)$ & $64.813(13.19)$ & $69.037(13.94)$ & 0.842 \\
\hline Femininity/masculinity scale (Mf) & $50.636(9.29)$ & $47.625(9.06)$ & $52.037(9.14)$ & 1.000 \\
\hline Paranoia scale $(\mathrm{Pa})$ & $72.205(13.29)$ & $68.250(10.71)$ & $74.593(14.51)$ & 0.221 \\
\hline Psychasthenia scale (Pt) & $74.114(10.51)$ & $71.875(11.46)$ & $75.296(10.08)$ & 0.551 \\
\hline Schizophrenia scale (Sc) & 74.841 & $70.125(9.37)$ & $77.815(11.81)$ & $0.052^{*}$ \\
\hline Mania scale (Ma) & $56.455(11.37)$ & $54.750(15.97)$ & $57.407(12.29)$ & 0.233 \\
\hline Social introversion scale (Si) & $69.233(13.49)$ & $65.200(11.78)$ & $72.185(10.28)$ & 0.529 \\
\hline Anxiety scale (A) & $73.735(11.49)$ & $70.308(9.71)$ & $76.450(5.91)$ & $0.051^{*}$ \\
\hline Repression scale (R) & $62.029(8.14)$ & $63.462(13.47)$ & $61.300(14.07)$ & 0.900 \\
\hline $\operatorname{ER} \alpha \operatorname{mRNA}\left(2^{-\Delta \Delta c t}\right)$ & $0.254(0.05)$ & $0.251(0.05)$ & $0.254(0.06)$ & 0.338 \\
\hline ER $\alpha$ protein (pg/ml) & $4.658(0.55)$ & $4.583(0.49)$ & $4.687(0.58)$ & 0.510 \\
\hline $\operatorname{ER} \beta$ mRNA $\left(2^{-\Delta \Delta c t}\right)$ & $0.231(0.04)$ & $0.231(0.03)$ & $0.231(0.04)$ & 0.782 \\
\hline ERß protein $(\mathrm{ng} / \mathrm{ml})$ & $4.624(0.71)$ & $4.601(0.69)$ & $4.649(0.75)$ & 0.712 \\
\hline
\end{tabular}

ED-I - first depression episode, rDE - recurrent depression episodes, Me - mean, SD - standard deviation, ${ }^{*} p$ statistically significant, ER $\alpha$ - oestrogen receptor $\alpha$, ER $\beta$ - oestrogen receptor $\beta$ 
Table 3. Descriptive statistics of the analysed variables - sex

\begin{tabular}{|c|c|c|c|c|}
\hline $\begin{array}{l}\text { Variable } \\
\text { Me (SD) }\end{array}$ & $\begin{array}{c}\text { All subjects } \\
n=44\end{array}$ & $\begin{array}{l}\text { Women } \\
n=31\end{array}$ & $\begin{array}{c}\text { Men } \\
n=13\end{array}$ & $\begin{array}{c}\text { W vs. } M \\
\text { Mann-Whitney } \\
U \text { test }\end{array}$ \\
\hline Hypochondria scale $(\mathrm{Hd})$ & $73.682(15.08)$ & $73.677(14.38)$ & $73.692(17.27)$ & 0.997 \\
\hline Depression scale (D) & $78.068(14.21)$ & $78.581(13.07)$ & $76.846(17.14)$ & 0.716 \\
\hline Hysteria scale (Hy) & $72.773(15.97)$ & $70.806(14.64)$ & $77.462(18.55)$ & 0.211 \\
\hline Psychopathic deviate scale (Pd) & $67.318(13.54)$ & $65.323(10.65)$ & 72.077 (18.39) & 0.132 \\
\hline Femininity/masculinity scale (Mf) & $50.636(9.29)$ & $48.742(9.27)$ & $55.154(7.94)$ & $0.035^{*}$ \\
\hline Paranoia scale $(\mathrm{Pa})$ & $72.205(13.29)$ & $72.839(12.31)$ & $70.692(15.82)$ & 0.631 \\
\hline Psychasthenia scale (Pt) & $74.114(10.51)$ & $73.516(9.49)$ & $75.538(12.95)$ & 0.566 \\
\hline Schizophrenia scale (Sc) & 74.841 & $75.677(10.89)$ & $72.846(12.69)$ & 0.457 \\
\hline Mania scale $(\mathrm{Ma})$ & $56.455(11.37)$ & $54.548(13.31)$ & $61.001(13.34)$ & 0.150 \\
\hline Social introversion scale (Si) & $69.233(13.49)$ & $70.633(10.29)$ & $66.001(13.77)$ & 0.228 \\
\hline Anxiety scale (A) & $73.735(11.49)$ & $72.720(8.31)$ & $76.556(7.35)$ & 0.231 \\
\hline Repression scale (R) & $62.029(8.14)$ & $63.760(13.56)$ & $57.222(12.75)$ & 0.217 \\
\hline $\mathrm{ER} \alpha \mathrm{mRNA}\left(2^{-\Delta \Delta c t}\right)$ & $0.254(0.05)$ & $0.249(0.06)$ & $0.264(0.06)$ & 0.417 \\
\hline ER $\alpha$ protein $(\mathrm{pg} / \mathrm{ml})$ & $4.658(0.55)$ & $4.605(0.53)$ & $4.784(0.57)$ & 0.325 \\
\hline $\operatorname{ER} \beta$ mRNA $\left(2^{-\Delta \Delta c t}\right)$ & $0.231(0.04)$ & $0.232(0.03)$ & $0.229(0.04)$ & 0.813 \\
\hline ER $\beta$ protein $(\mathrm{ng} / \mathrm{ml})$ & $4.624(0.71)$ & $4.638(0.66)$ & $4.591(0.85)$ & 0.842 \\
\hline
\end{tabular}

\section{Discussion}

This paper is the first to evaluate the relationship between personality traits measured by the MMPI-2 questionnaire and the expression of the genes encoding $\alpha$ and $\beta$ receptors in patients diagnosed with depression. Although the study group was not numerous, we were able to confirm the interrelations described in the literature (in most cases, however, referring to animal models).

In the literature there are few studies evaluating the relationship between polymorphisms of the genes encoding oestrogen receptors and traits of emotional functioning of the subjects. Consequently, the A-351G gene polymorphism responsible for encoding oestrogen receptor $\alpha$ was found to be correlated with the premenstrual syndrome (PMS; or premenstrual dysphoric disorder - PMDD). In women with PMS/PMDD the GG allele was found to be eight times more common and was connected with the intensity of the symptoms reported by the examined subjects [41]. In addition to somatic ailments, the following behavioural and emotional symptoms are also present in the case of PMS/ PMDD [42, 43]: low mood and self-acceptance and sense of hopelessness; increased level of anxiety, sensitivity, increased tension; affective instability - frequent and easy change of affect; persistent strong feeling of anger or significantly increased irritability; reduced interest in doing everyday work and duties; sense of hindered concentration; lack of enthusiasm (delight, enthusiasm, joy), easy fatigue; eating disorders - overeating or starvation; sleep disorders - excessive sleepi- ness or insomnia; the feeling of lack of control or being overburdened; physical symptoms - breast tenderness, distension with gas, body weight increase, headaches, joint and muscle pains [44]. Yen et al. [42] recorded interesting results from the perspective of our study. The level of oestradiol measured prior to menstruation was negatively correlated with anxiety and fear levels experienced by the women with PMDD. According to Miller et al. [45], selected polymorphisms of the ERS1 gene in women diagnosed with PMDD correlate with personality traits such as: lower Emotional Stability (L0058), lower Impression Management (L0058) (higher scores serve as an indication for a greater chance to project a socially desirable image), higher Harm Avoidance (L0026, L0060, L0061), higher Neuroticism (L0026), and higher Abstractedness (L0025, L0026, L0060, L0061, L0055, L0058) (idea-oriented and imaginative thinking is reflected by higher scores, whereas low scores indicate concrete practical thinking) [45]. Gade-Andavolu et al. [46] observed, however, that the SS allele of the gene encoding ESR 1 is associated with the tendency to compromise, and Prichard et al. [47] found that in men it may be combined with anti-social personality traits. Alternatively, Feng et al. [48], when assessing the relationship between the rs9340799 polymorphism of the ESR1 gene and the occurrence and severity of depression symptoms among teenagers, victims of natural disasters (earthquakes), found that the possession of the AA allele of the evaluated gene was the risk factor of depression in the group of women. Furthermore, Keyes et al. [49] confirmed the association of the AA al- 
lele of the ESR2 RS4986938 gene with an increased risk of depression symptoms during life (in the group of women). Doi et al. [50] observed that severities in the impairment of social interaction and emotional regulation were linked to SNPs in ESR1 rs11155819 and ESR2 rs1152582 in a group of 96 individuals with autism spectrum disorder (ASD). However, Giegling et al. [51] did not validate any link or connection between the indicated polymorphisms of the ESR $\alpha$ encoding gene (rs827421, rs1913474, rs1801132, rs722207, rs974276, and rs910416) and an elevated risk of suicidal or aggressive behaviour.

Oestrogen receptors were found to be present in the area of the prefrontal cortex and the hippocampus [52], as well as within the hypothalamus and the amygdala [53]. These brain regions are not only associated with the risk of depression [31] but are also involved in social cognition processes and regulation of aggressive behaviour [31]. The presence of oestrogen receptors was also confirmed in the dorsal part of the raphe nucleus, i.e. the brain area crucial for the production of neurotransmitter serotonin [54]. In their animal model study, Yang et al. [54] examined the influence of changeable oestradiol doses (10 and $50 \mu \mathrm{g} / \mathrm{rat}$ per day for 11 consecutive days) on the behaviour of the animals and on the expression of tryptophan hydroxylase (TPH) and glucocorticoid receptor in the raphe nucleus of ovariectomised rats that were undergoing a forced swim test. According to the quoted authors, the physiological dose of oestradiol decreased the incidence of depressive behaviour in the examined animals and increased the expression of TPH - an enzyme involved in the serotonin biosynthesis pathway. Interestingly, a high dose of oestradiol showed no antidepressant effect. In such cases the level of corticosterone increases simultaneously, which may reverse tryptophan hydroxylase expression of in the raphe nucleus [54].

Oestradiol participation in the aetiology of depressive disorders may be associated not only with the regulation of tryptophan hydroxylase 2 but also with the expression of monoamine oxidase $A$ and $B$, serotonin transporter, and serotonin-1A receptor. This effect is related to the binding of oestradiol to the intracellular oestrogen receptor, which interacts with oestrogen response elements in the tryptophan hydroxylase 2 promoter sequences, the transporter of serotonin and monoamine oxidase B [55].

Oestrogen receptor $\alpha$ is important for the proper course of sexual behaviour, while both ER $\alpha$ and ER $\beta$ modulate the anxiety response by influencing the level of arousal [56, 57]. According to Sharma and Thakur [58] and Le Moëne et al. [59], ER $\beta$ in the central amygdala is responsible to a certain extent for the well-established anxiolytic effects of oestrogens and may modulate the level of arousal. On the other hand, in aversive or threatening situations, ER $\alpha$ in the ventromedial nucleus of the hypo- thalamus has an anxiogenic action. ER $\beta$ phosphorylates and activates intracellular second messenger proteins and regulates protein expression of genes involved in neurological functions. It also promotes neurogenesis, modulates the neuroendocrine regulation of stress response, confers neuroprotection against ischaemia and inflammation, and reduces anxiety- and depression-like behaviour [3]. These results correspond with the results recorded by us for the examined women: a positive relationship between the scale of psychopathy $(R=0.36, p=0.04)$, paranoia $(R=0.43, p=0.01)$, and mania $(R=0.38, p=0.03)$ and the expression the ER $\alpha$ receptor encoding gene at the mRNA level. There is a correlation between these scales and an elevated sense of experienced anxiety. In contrast, a negative relationship was found and confirmed between the scale of mania and ER $\beta$ receptor gene expression at the level of mRNA $(R=-0.39, p=0.03)$ and the protein level $(R=-0.36, p=0.04)$, which indicates that higher ER $\beta$ expression was linked with the calming down of the patients.

Sharma and Thakur [58] observed a significant $(p<0.05)$ increase in ER $\alpha$ mRNA and protein expression levels in response to a mild yet chronic stress stimulus, while the expression of ER $\beta$ in the prefrontal cortex, hippocampus, and amygdala was significantly reduced. These changes affected both the prefrontal cortex region, the area of the hippocampus, and the amygdala and were associated with increased anxiety and depressive symptoms. At the same time, the quoted authors reported a decrease of dendritic complexity with concomitant increase in spine density in the medial prefrontal cortex, CA3 area of the dorsal hippocampus, and basolateral complex of the amygdala [58]. ER $\beta$ and oxytocin are thought to modulate the action of the hypothalamic-pituitary-adrenal axis (HPA) by reducing ACTH and corticosterone levels [60].

In addition, male mice devoid of the $\alpha$ oestrogen receptor became less sensitive to social stimuli [61], which is also consistent with the biopsychosocial model of depression [31]. According to Frankiensztajn et al. [29], oestradiol may modulate synaptic plasticity in the central part of the amygdala, thus affecting the ability to process social information. These findings are also confirmed by Hyer et al. [62]. Interesting research results are presented by a team led by Adzic et al. [63]. The authors explored the impact of fluoxetine on mitochondrial ER $\alpha$ and ER $\beta$ (total and phospho-pER $\beta$ ) together with their link with the activity of cytochrome $c$ (cyt c) oxidase and apoptotic Bcl2/Bax-molecules in the mitochondria of the hippocampus in female and male rats subject to chronic isolation. No influence of chronic isolation on the expression of mitochondrial $E R \alpha$ in both sexes was found, with simultaneous decrease of mitochondrial ER $\beta$ expression and increase of $p E R \beta$ expression in both sexes. The antidepressant treatment applied reversed these processes [63]. In other experiments, a team led by Losch et al. [64] considered the ex- 
pression at the protein level of the gene encoding ER $\alpha$ in the accumbens nucleus region as a protective factor reducing the risk of depression development in the examined animals. The accumbens nucleus is part of the human reward system, the main motivating system of behaviour, and the overexpression of ESR1 in this area was associated with increased stress resilience.

In addition, Findkin et al. [65] observed that a relatively recently discovered oestrogen receptor, i.e. G protein-coupled oestrogen receptor 1 (GPER1), may be relevant in the aetiology of depressive disorders. The level of GPER1 in 56 new patients diagnosed with depression was significantly higher compared with an equivalent group of healthy subjects. Furthermore, it positively correlated with depression symptom intensity as measured with the use of the Hamilton Depression Rating Scale. The mechanism of its action may both increase and decrease the probability of anxiety behaviour [66].

To sum up, it is possible to conclude that there is a close link between the HPA (hypothalamic-pituitaryadrenal) axis, which has a significant role in stress response, and the HPG (hypothalamic-pituitary-gonadal) axis [67]. Undoubtedly, this matter still requires further and thorough research.

\section{Conclusions}

Personality traits may be linked with the expression of the genes encoding the oestrogen receptors $E R \alpha$ and ER $\beta$ among patients with depressive disorders.

\section{Limitations}

In the analysis of the results, the number of respondents should be taken into account. The analysis was carried out on a group of people treated for depression. The biochemical evaluation used venous blood.

\section{Disclosure}

The authors report no conflict of interest.

\section{References}

1. Meyer K, Korz V. Estrogen receptor $\alpha$ functions in the regulation of motivation and spatial cognition in young male rats. PLoS One 2013; 8: e79303.

2. Agmo A, Choleris E, Kavaliers M, et al. Social and sexual incentive properties of estrogen receptor alpha, estrogen receptor beta, or oxytocin knockout mice. Genes Brain Behav 2008; 7: 70-77.

3. Vargas KG, Milic J, Zaciragic A, et al. The functions of estrogen receptor beta in the female brain: A systematic review. Maturitas 2016; 93 41-57.

4. Nelson LR, Bulun SE. Estrogen production and action. J Am Acad Dermatol 2001; 45 (3 Suppl): 116-124.

5. Kudwa AE, Michopoulos V, Gatewood JD, Rissman EF. Roles of estrogen receptors alpha and beta in differentiation of mouse sexual behavior Neuroscience 2006; 138: 921-928.
6. Vermeersch H, T'sjoen G, Kaufman JM, Van Houtte M. ESR1 polymorphisms, daily hassles, anger expression, and depressive symptoms in adolescent boys and girls. Horm Behav 2013; 63: 447-453.

7. Dupuis ML, Conti F, Maselli A, et al. The natural agonist of estrogen receptor $\beta$ silibinin plays an immunosuppressive role representing a potential therapeutic tool in rheumatoid arthritis. Front Immunol 2018; 9: 1903.

8. Sandweiss AJ, Cottier KE, Mclntosh MI, et al. 17- $\beta$-Estradiol induces spreading depression and pain behavior in alert female rats. Oncotarget 2017; 8: 114109-114122.

9. Georgiou P, Zanos P, Jenne CE, Gould TD. Sex-specific involvement of estrogen receptors in behavioral responses to stress and psychomotor activation. Front Psychiatry 2019; 10: 81.

10. De Marinis E, Fiocchetti M, Acconcia F, et al. Neuroglobin upregulation induced by 17 beta-estradiol sequesters cytocrome $c$ in the mitochondria preventing $\mathrm{H} 2 \mathrm{O} 2$-induced apoptosis of neuroblastoma cells. Cell Death Dis 2013; 4: e508.

11. Spence RD, Wisdom AJ, Cao Y, et al. Estrogen mediates neuroprotection and anti-inflammatory effects during EAE through ERalpha signaling on astrocytes but not through ERbeta signaling on astrocytes or neurons. J Neurosci 2013; 33: 10924-10933.

12. Scharfman, HE, Maclusky, NJ. Estrogen and brain-derived neurotrophic factor (BDNF) in hippocampus: complexity of steroid hormone-growth factor interactions in the adult CNS. Front Neuroendocrinol 2006; 27: 415-435.

13. Mogi K, Takanashi H, Nagasawa M, Kikusui T. Sex differences in spatiotemporal expression of $A R, E R \alpha$, and $E R \beta$ mRNA in the perinatal mouse brain. Neurosci Lett 2015; 584: 88-92.

14. Trainor BC, Greiwe KM, Nelson RJ. Individual differences in estrogen receptor alpha in select brain nuclei are associated with individual differences in aggression. Horm Behav 2006; 50: 338-345.

15. Witty CF, Gardella LP, Perez MC, Daniel JM. Short-term estradiol administration in aging ovariectomized rats provides lasting benefits for memory and the hippocampus: a role for insulin-like growth factor-l. Endocrinology 2013; 154: 842-852.

16. Meyer K, Korz V. Age dependent differences in the regulation of hippocampal steroid hormones and receptor genes: relations to motivation and cognition in male rats. Horm Behav 2013; 63: 376-384.

17. Estrada CM, Ghisays V, Nguyen ET, et al. Estrogen signaling in the medial amygdala decreases emotional stress responses and obesity in ovariectomized rats. Horm Behav 2018; 98: 33-44.

18. Kadel S, Kovats S. Sex Hormones Regulate Innate Immune Cells and Promote Sex Differences in Respiratory Virus Infection. Front Immunol 2018; 9: 1653.

19. Maciuszek M. To be a woman, to be a woman - the influence of estrogen on the functioning of the immune system. Wszechświat 2016; 117: 308-14.

20. Kovats S. Estrogen receptors regulate an inflammatory pathway of dendritic cell differentiation: mechanisms and implications for immunity. Horm Behav 2012; 62: 254-262.

21. Moulton VR. Sex Hormones in Acquired Immunity and Autoimmune Disease. Front Immunol 2018; 9: 2279.

22. Ascenzi P, Bocedi A, Marino M. Structure-function relationship of estrogen receptor alpha and beta: impact on human health. Mol Aspects Med 2006; 27: 299-402.

23. Choleris E, Clipperton-Allen AE, Phan A, et al. Estrogenic involvement in social learning, social recognition and pathogen avoidance. Front Neuroendocrinol 2012; 33: 140-159.

24. Zielniok K, Gajewska M, Motyl T. Molecular actions of $17 \beta$-estradiol and progesterone and their relationship with cellular signaling pathways. Postepy Hig Med Dosw (Online) 2014; 68: 777-792.

25. Ciana P, Raviscioni M, Mussi P, et al. In vivo imaging of transcriptionally active estrogen receptors. Nat Med 2003; 9: 82-86.

26. Bansal S, Chopra K. Differential role of estrogen receptor modulators in depression-like behavior and memory impairment in rats with postmenopausal diabetes. Menopause 2015; 22: 1117-1124.

27. Jaillon S, Berthenet K, Garlanda C. Sexual Dimorphism in Innate Immunity. Clin Rev Allergy Immunol. 2019;56(3):308-21.

28. Huo L, Straub RE, Roca C et al. Risk for premenstrual dysphoric disorder is associated with genetic variation in ESR1, the estrogen receptor alpha gene. Biol Psychiatry 2007; 62: 925-933. 
29. Frankiensztajn LM, Gur-Pollack R, Wagner S. A combinatorial modulation of synaptic plasticity in the rat medial amygdala by oxytocin, urocortin3 and estrogen. Psychoneuroendocrinology 2018; 92: 95-102.

30. Bhatia A, Sekhon H, Kaur G. Sex hormones and immune dimorphism. ScientificWorldJournal 2014; 2014: 159150.

31. Gałecki P, Talarowska M. Neurodevelopmental theory of depression. Prog Neuropsychopharmacol Biol Psychiatry 2018; 80 (Pt C): 267-272.

32. Talarowska M, Bliźniewska K, Szemraj J, et al. Personality traits as a possible factor in the inflammatory response in the first depression episode and in recurrent depressive disorders. Eur J Psychiat 2018; 32: 63-71.

33. Talarowska M, Kowalczyk M, Maes M, et al. Immune to happiness - inflammatory process indicators and depressive personality traits. Arch Med Sci 2019; DOI: https://doi.org/10.5114/aoms.2019.83146.

34. World Health Organization. International Statistical Classification of Diseases and Related Health Problems $10^{\text {th }}$ Revision (ICD-10). World Health Organization, Genewa 2015.

35. Hamilton M. A rating scale for depression. J Neurol Neurosurg Psychiatry 1960; 23: 56-62.

36. Demyttenaere K, De Fruyt J. Getting what you ask for: on the selectivity of depression rating scales. Psychothery Psychosom 2003; 72: 61-70.

37. Kessler RC, Ustün TB. The World Mental Health (WMH) Survey Initiative Version of the World Health Organization (WHO) Composite International Diagnostic Interview (CIDI). Int J Methods Psychiatr Res 2004; 13: 93-121.

38. Kucharski T. Selected issues connected with polish adaptation of the MMPI-2 and the MMPI-A. CPKiROZ, Torun 2002.

39. Sellbom M. The MMPI-2-Restructured Form (MMPI-2-RF): Assessment of Personality and Psychopathology in the Twenty-First Century. Annu Rev Clin Psychol 2019; 15: 149-177.

40. Kirkwood B, Sterne J. Essential medical statistics, $2^{\text {nd }}$ ed. Wiley-Blackwell, Hoboken 2003.

41. Pakharenko L. Effect of estrogen receptor gene ESR1 polymorphism on development of premenstrual syndrome. Georgian Med News 2014; 235: 37-41.

42. Yen JY, Wang PW, Su CH, et al. Estrogen levels, emotion regulation, and emotional symptoms of women with premenstrual dysphoric disorder: The moderating effect of estrogen receptor $1 \alpha$ polymorphism. Prog Neuropsychopharmacol Biol Psychiatry 2018; 82: 216-223.

43. Słopień R. Mood disorders in women with premature ovarian insufficiency. Prz Menopauzalny 2018; 17: 124-126.

44. Diagnostic and Statistical Manual of Mental Disorders (DSM-5), Fifth Edition. APA, 2013.

45. Miller A, Vo H, Huo L, et al. Estrogen receptor alpha (ESR-1) associations with psychological traits in women with PMDD and controls. J Psychiatr Res 2010; 44: 788-794

46. Gade-Andavolu R, Macmurray J, Comings DE, et al. Association between the estrogen receptor TA polymorphism and Harm avoidance. Neurosci Lett 2009; 467: 155-158.

47. Prichard ZM, Jorm AF, Mackinnon A, Easteal S. Association analysis of 15 polymorphisms within 10 candidate genes for antisocial behavioural traits. Psychiatr Genet 2007; 17: 299-303.

48. Feng Y, Lin J, Guo Q, et al. Longitudinal interactions of estrogen receptor alpha gene rs9340799 with social-environmental factors on depression in adolescents after Wenchuan earthquake. J Clin Neurosci 2017; 45: 305-310.

49. Keyes K, Agnew-Blais J, Roberts AL, et al. The role of allelic variation in estrogen receptor genes and major depression in the Nurses' Health Study. Soc Psychiatry Psychiatr Epidemiol 2015; 50: 1893-1904.

50. Doi H, Fujisawa TX, Iwanaga R, et al. Association between single nucleotide polymorphisms in estrogen receptor $1 / 2$ genes and symptomatic severity of autism spectrum disorder. Res Dev Disabil 2018; 82: 20-26.

51. Giegling I, Rujescu D, Mandelli L, et al. Estrogen receptor gene 1 variants are not associated with suicidal behavior. Psychiatry Res 2008; 160: 1-7.

52. Grigorova M, Sherwin BB. No differences in performance on test of working memory and executive functioning between healthy elderly postmenopausal women using or not using hormone therapy. Climacteric 2006; 9: 181-194

53. Ogawa S, Choleris E, Pfaff D. Genetic influences on aggressive behaviors and arousability in animals. Ann N Y Acad Sci 2004; 1036: 257-266.

54. Yang F, Cheung A, Tao J, et al. Physiological dosages of estradiol and diarylpropionitrile decrease depressive behavior and increase tryptophan hydroxylase expression in the dorsal raphe nucleus of rats subjected to the forced swim test. Neuroreport 2019; 30: 66-70.

55. Hernández-Hernández OT, Martínez-Mota L, Herrera-Pérez JJ, JiménezRubio G. Role of estradiol in the expression of genes involved in serotonin neurotransmission: implications for female depression. Curr Neuropharmacol 2019; 17: 459-471.

56. Lynch JF 3rd, Winiecki P, Vanderhoof T, et al. Hippocampal cytosolic estrogen receptors regulate fear generalization in females. Neurobio Learn Mem 2016; 130: 83-92.

57. Ogawa S, Tsukahara S, Choleris E, Vasudevan N. Estrogenic regulation of social behavior and sexually dimorphic brain formation. Neurosci Biobehav Rev 2018 Oct 27. pii: S0149-7634(18)30277-X. doi: 10.1016/j. neubiorev.2018.10.012. [Epub ahead of print]

58. Sharma HR, Thakur MK. Correlation of ER $\alpha / E R \beta$ expression with dendritic and behavioural changes in CUMS mice. Physiol Behav 2015; 145 71-83

59. Le Moëne O, Stavarache M, Ogawa S, et al. Estrogen receptors $\alpha$ and $\beta$ in the central amygdala and the ventromedial nucleus of the hypothalamus: Sociosexual behaviors, fear and arousal in female rats during emotionally challenging events. Behav Brain Res 2019; 367: 128-142.

60. Acevedo-Rodriguez A, Mani SK, Handa RJ. Oxytocin and estrogen receptor in the brain: an overview. Front Endocrinol (Lausanne) 2015; 6: 160

61. Imwalle DB, Scordalakes EM, Rissman EF. Estrogen receptor alpha influences socially motivated behaviors. Horm Behav 2002; 42: 484-491.

62. Hyer MM, Khantsis S, Venezia AC, et al. Estrogen-dependent modifications to hippocampal plasticity in paternal California mice (Peromyscus californicus). Horm Behav 2017; 96: 147-155.

63. Adzic M, Mitic M, Radojcic M. Mitochondrial estrogen receptors as a vulnerability factor of chronic stress and mediator of fluoxetine treatment in female and male rat hippocampus. Brain Res 2017; 1671: 77-84.

64. Lorsch ZS, Loh YE, Purushothaman I, et al. Estrogen receptor $\alpha$ drives pro-resilient transcription in mouse models of depression. Nat Commun 2018; 9: 1116.

65. Findikli E, Kurutas EB, Camkurt MA, et al. Increased Serum G Proteincoupled Estrogen Receptor 1 Levels and Its Diagnostic Value in Drug Naïve Patients with Major Depressive Disorder. Clin Psychopharmacol Neurosci 2017; 15: 337-342.

66. Borrow AP, Handa RJ. Estrogen Receptors Modulation of Anxiety-Like Behavior. Vitam Horm 2017; 103: 27-52.

67. Fenchel D, Levkovitz Y, Vainer E, et al. Beyond the HPA-axis: The role of the gonadal steroid hormone receptors in modulating stress-related responses in an animal model of PTSD. Eur Neuropsychopharmacol 2015; 25: $944-957$ 